\title{
THE KING'S PRINTING HOUSE UNDER THE STUARTS.
}

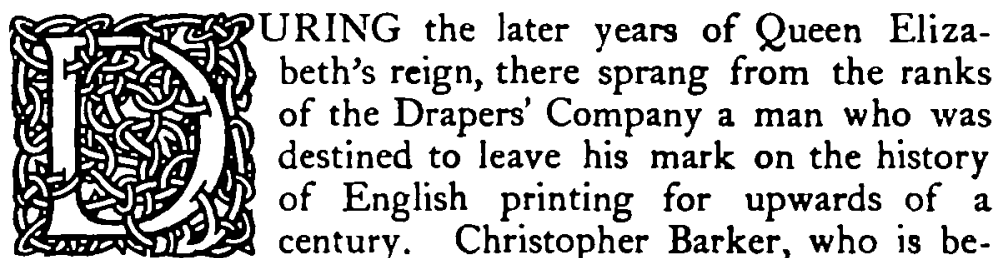
lieved to have been related to Sir Christopher Barker, Garter King of Arms, began to publish books in 1569 (Arber, i. 398). On the death of Richard Jugge in 1577 , the office of Royal Printer was granted to Sir Thomas Wilkes, who, for a consideration, transferred a portion of it to Christopher Barker, and on the disgrace of Wilkes in $15^{89}$ Barker obtained an exclusive patent for himself and his son Robert. Some years before his death Christopher retired from business and lived in the manor house of Sudely or Southly, near Datchet. He died in I 599, and was buried in the parish church of Datchet, where a monument still remains to his memory.

At the accession of James I. in 1603, Robert Barker held the office of King's Printer by virtue of the reversionary patent granted by the late Queen to his father Christopher.

Very few biographical details are available concerning Robert Barker. He was the eldest son, and was in all probability born in the manor house of Sudely or Southly, near Datchet, in the county of Bucks, where his father had lived for many years. He was brought up to the trade of a printer, and obtained the freedom of the Company of Stationers on the 25 th June, 1589 , from which time, until his father's death in 1599, he held a partner-

II.

B $\mathbf{B}$ 
ship in the royal printing house. $\mathrm{He}$ is said to have married Rachel, a daughter of William Day, afterwards Bishop of Winchester, who died in 1607, leaving him with a family of five sons, Christopher, Robert, Charles, Francis, and Matthew, and three daughters. From a statement made by his younger children at a later date, Robert Barker's income at this time was $€ 3,000$ a year, and he possessed, besides, great personal estates.

The patent which Barker held gave him the sole monopoly of printing the Bible, either as a whole or in parts, the Book of Common Prayer, and all official documents, and this was extended by King James to include all Statutes, hitherto the monopoly of other printers. But over and above the official work, for which we may be sure he recouped himself, there is reason to believe the office of King's Printer brought with it a large amount of outside custom, and was a highly profitable business.

Soon after James's accession, Robert Barker obtained the reversion of the office for his eldest son Christopher (grandson of Chrisopher I.), and a further reversion for thirty years to his second son Robert, after the death of Christopher and himself. In 1604 a conference of divines was held at Hampton Court, when it was decided to issue a new translation of the Scriptures. This, which is known as the 'authorized version,' was finished in 1611 , and the whole cost of its printing is said to have been borne by Robert Barker, the King's Printer. Whether it was this that crippled him, or whether, as seems more probable, he had for years been living above his income, or speculating in other ways, the fact remains that very shortly after the issue of the Bible the office of King's Printer passed away from him; and, though nominally recovered for a short period, and carrying on the name of the family till the close of the century, was never really in the hands of those whose names appear in the imprints.

Students of English printing have been sorely puzzled to account for the numerous changes that are found in the 
imprints of books printed by the King's printers in the reigns of James and Charles I. First we meet with Robert Barker alone, then we find Bonham Norton and John Bill, and Robert Barker and John Bill in conjunction at different times. The provincial imprints on the proclamations and other documents issued by Charles I. after he left London are still more puzzling, as it has been established beyond doubt that Robert Barker, whose name they bear, was in prison from 1635 to 1645 , and, finally, the numerous changes that are subsequently found, make it difficult to know who wass, or who was not, the King's Printer.

A chance discovery at the Record Office, with the help of the State Papers, and the Reports of the Historical Manuscripts Commissioners, has supplied the material necessary for giving a fairly clear history of the King's Printing House under the Stuarts, which I hope will be found to settle the doubtful points, and to throw light on much that has hitherto been unknown. The most important of these documents are the records of the Court of Chancery.

In 1618 Robert Barker commenced a suit in that court against Bonham Norton and John Bill for the recovery of a moiety of the office and stock of the King's Printing House. Bonham Norton, the principal defendant in this action, was, next to Barker, the most important stationer in the city of London. He was the only son of William Norton, of the King's Arms, in St. Paul's Churchyard, who had married one of the daughters of William Bonham, 'stationer,' the friend and contemporary of John Rastell. Norton was a native of Shropshire ; in the subsidy rolls of the reign of Henry VIII. the name is found in the neighbourhood of Church Stretton, there being a Thomas Norton in the parish of Bloomfield, and a Richard Norton in the parish of Onybury (Lay Subsidies, Shropshire, P.R.O.). It was from the latter place, most likely, that this particular family came, as William Norton was possessed of property there at the time of his death; but the name is also found 
at Cleobury Mortimer, and Billingsly, in the same parish. Bonham Norton was born in 1565 , and was made free of the Company of Stationers in 1594 . His father had died in the previous year, leaving him the bulk of his property (P. C. C., 5 Dixey). He married Jane, the daughter of Sir Thomas Owen, of Condover, and he had a family of six sons, William, Thomas, Arthur, Roger, John, and George, and five daughters. $\mathrm{He}$ was master of the Stationers' Company in 1613,1626 , and 1629 .

In 16 I 2 Bonham Norton, already a rich man, received a legacy from his cousin John Norton, also a Shropshire man, and the printer of Sir Henry Sa llle's edition of 'Chrysostom' (P. C. C., 5 Capell).

The other defendant, John Bill, was another native of Shropshire, the son of Walter Bill, of Wenlock. He apprenticed himself to John Norton, and was admitted a freeman of the Stationers' Company in r6or. He will be remembered as the stationer who was employed by $\mathrm{Sir}$ Thomas Bodley to purchase books abroad for his new library at Oxford.

Robert Barker, in his bill of complaint, says that for years he had been on intimate terms with Bonham Norton, and that in 16 I 5 a marriage was arranged between his eldest son Christopher, and Norton's eldest daughter Sarah. After reciting the settlements made on both sides he goes on.

- And afterwards [i.e. after the marriage] your said orator did place the said Christopher his sonne in the present execution of your said orator's office of his Majesties printinge, hoapinge and expecting that the said Bonham Norton, who had some interest in some part of that office during your said orator's life, would ayde and ' 'irect your orator's said sonne for his best advantage in the execution of the said office of printinge (hee the said Bonham Norton being also a stationer and one of the ancients of that Company)... And thereuppon your said orator did make choice of the said Bonham Norton $\&$ one John Bill (named by the said Bonham Norton) 
to make them . . co-partners in trust of the benefit of the said office for the good of your said orators sonne ... But the said Bonham Norton \& the said John Bill of London also stationer, being imployed in the said office of printinge as aforesaid and perceiving great profit and benefit to arise $\&$ come thereof, and being desirous to enrich themselves thereby \& finding that your said orator $\&$ his said sonne Christopher after three years experience of their hard dealing ... were determined to have noe longer partnership with the said Norton \& Bill, but to make their best benefit by sale of the said office: the said Norton \& Bill did cunningly devise \& practise how to obteyne \& get the said office of printing wholly into their own hands and to discourage and divert all others from dealing therewith, and therefore not onely concealed and deteyned the benefit and profit of the said office from your said orator \& your said orators eldest sonne, \& refused to give any profit accompt or reckoninge of the said office for the space of three yeares $\&$ upwards amounting to the sum of three thousand pounds $\&$ upwards $\&$ the same was altogether unknown unto your said orator, for that ... Bonham Norton had persuaded your orator's eldest sonne Christopher to conceal his [? B. N.'s] dealings from your said orator, \& to deale with your said orator $\&$ obteyne of him ... to make sale of the said office vnto the said Norton \& the said John Bill \& unto noe other... Your said orator was persuaded by his . . . sonne Christopher to make sale of the said office unto ... Bonham Norton \& John Bill (the said office with the stock \& furniture thereunto belonging being well worth thirtie thousand pounds to bee sold according to the true value thereof) which in regard of farther promises \& great somes of money to be paid $\&$ of debts and accounts to be cleared $\&$ discharged . . . by the said Bonham Norton \& John Bill; the said Bonham Norton \& John Bill faythfully promised .... both before $\&$ after the subscribing 24 of certaine articles for the said bargain .... that they 


\section{$35^{8}$ THE KING'S PRINTING HOUSE}

would be true accomptants to your said orator \& to his eldest sonne Christopher (to whom they were bound formally in $4000^{\text {li }}$ a peece for that purpose) of all the profits of the said office during the lives of your . . . orator's sonne Christopher \& of your . . . orator \& the longer liver of them; and they also then faithfully promised \& agreed that if your said orator or his said sonne (after the finishing of the said bargain) within the space of one whole yeare \& a daie after the assignment of the said office could gett or procure any greater some or benefit for the said office, stock or furniture, then that they would give true accompt unto your said orator for all the reckonings between them $\&$ of the said yeares profits of the said office $\&$ to discharge $\&$ paye two hundred $\&$ two pounds unto some of the Company of Stationers which some of the Company demanded for satisfaction of imperfect books, \& suffer your said orator \& his sonnes Christopher \& Robert to make their best benefit thereof, and thereupon about the month of July in the $15^{\text {th }}$ yeare of His Majesty's reign (i.e. 16 17) your orator $\&$ his said two sonnes . . . did make \& depute the said Bonham Norton \& John Bill their deputies and assignes in the said office \& did assigne over all their interest in the said office of His Majesties printer unto . . Bonham Norton $\&$ John Bill for and in consideration of the som of $6000^{\text {li }}$ $\& 500^{l i}$ to bee paid unto your said orators (and for $\&$ in consideration of the some of $200^{\text {li }}$ which your . . . orator did then stand indebted unto the said John as the said John Bill pretended $\&$ for $\&$ in consideration of the some of $200^{\text {li }}$ which the said Christopher Barker stands indebted to the stock . . . as both the said Bonham Norton \& John Bill falsely pretended) at certain times agreed on - $\therefore$ \& the overplus of the value thereof was agreed to be paid unto your orator's said two sonnes Christopher \& Robert according to the interest which either of them had therein.' . . .

Barker goes on to say that shortly after the signing of 
this agreement a fire occurred in his library at Southly, in which all the deeds were destroyed, and that taking advantage of his misfortune, Bonham Norton and John Bill had refused to yield possession of the office at the end of the twelve months and a day, and had refused to render any account of the profits, and that further Bonham Norton had not paid the marriage portion agreed on.

Norton's answer is set out at great length, covering two large skins of parchment closely written. He declares that when he gave his consent to his daughter's marriage, he believed Barker to be a richer man than he appeared to be. With regard to the assignment of the business he says, that in 1617 Barker and his son Christopher being greatly in debt, it was agreed between all the lessees of the patent, that they should try to sell all their interest in it and the lease of the printing house in Aldersgate Street, known as Northumberland House. No purchaser, however, could be found for it, and it was finally offered to Norton and Bill, who were not particularly anxious to have it. But Norton hearing that his son-in-law was indebted on his father's behalf in a sum of $f 5,000$, and thinking that the purchase of the office might free him, agreed on behalf of himself and John Bill to buy the reversions unreservedly. $\mathrm{He}$ absolutely denies that there was any condition or stipulation whatever. He further says that he and Bill had paid upwards of $f 5,800$ in settlement of the debts of the Barkers, a list of which is given, and these they considered should be set off against the purchase money of $f 6,500$. Finally, Norton declares that he and John Bill did not consider themselves bound in law to show their profits or the value of the things they had bought.

Three hitherto unknown facts are made clear from these documents : first, that Bonham Norton and John Bill were in partnership with Robert Barker before 1615 , probably at the time of the printing of the 'Authorized Version,' and it may very well be that they advanced money to Barker, to enable him to carry through the undertaking. 
We have proof of Bill's connection with the office at this date in a handsome edition of the 'Works' of King James printed in 16 I 6, which bears the imprint : 'London : Printed by Robert Barker and John Bill, Printers to the King's most excellent majestie. Anno 1616. Cum Priuilegio.' I

The second fact of importance is the date of the assignment of the business to Bonham Norton and John Bill, in July 1617. It proves that all books bearing Barker's name issued in that year were printed before July. The third is the location of Barker's printing house. Northumberland House was situated in St. Martin's Lane, Aldersgate Street. It had at one time belonged to the Percys, and Stow, in his 'Survey,' mentions it as a printing house, but does not say to whom it belonged.

The Court of Chancery referred the case for arbitration to Sir Henry Saville, of Eton, and Sir Marmaduke Darrell, but no settlement was arrived at; and finally, on the $7^{\text {th }}$ May, i6 I 9, the Court pronounced its decree. It held that there had been a release made by the plaintiff, Robert Barker, of all debts due to him in the office amounting to $£ 4,000$; and it also held that Norton had promised to reassure the office at any time within one year to Barker and his sons. The transaction, in fact, was only an assignment by Barker, as security for moneys lent, and the court styled Norton's denial as 'presumption.' He was ordered to reassign and reassure to Barker all his estate and title in the office and stock, and to render a true account of the profits before the following Christmas. Barker on his part was to repay Norton all such money as had been disbursed for him. John Bill was held to be a bona-fide purchaser, and was entitled to enjoy his share in the business. It was further decreed that nothing in the order was to be held to prejudice the co-partnership that existed before the assignment.

'It is difficult to understand why Norton's name was omitted from this imprint. 
This decree took effect at once, and explains the change of imprint which is found in books printed at the King's Printing House during the latter half of 16 I 9 and the early part of 1620 . Thus from July, 1617 , to May, 1619 , the imprint was Bonham Norton and John Bill, now it became once more Robert Barker and John Bill. Two editions of the Book of Common Prayer, one in folio and one in quarto, are found with the new imprint, as well as a duodecimo edition of the Bible; and a reissue of the unsold copies of the Works of King James with several additional pieces.

It is somewhat difficult to follow the subsequent proceedings in this strange and complicated case; Barker had clearly obtained what he wanted, reinstatement as King's Printer; but hardly was the ink dry on the lately pronounced decree than both parties entered into a fresh agreement, which received the assent of the Court on the $9^{\text {th }}$ December, 1619, the former decree being cancelled. By this new arrangement Barker was to pay Norton $f_{11}, 000$ for his moiety of the office, $f_{6}, 0,000$ of that amount to be paid before Michaelmas, I622, and $f_{1}, 000$ per annum by quarterly payments in the meantime. As security he was to convey to Norton and his heirs the manor of Sudely, or Southly, and if he failed in his payments, or any part of them, Norton was to be reinstated in the office. Under cover of this new agreement, Norton some time in the year 1620 , appears to have ejected Barker from the office, and again the imprints of the King's Printing House changed, becoming, for the second time, Bonham Norton and John Bill. As a result, all parties reappeared in the Court of Chancery, and the fight between them raged furiously for the next ten years, to the great profit of the lawyers. Barker endeavoured to regain possession of the office, and Norton harassed him in every way and evaded every decree or order of the court in order to gain time. It would be wearisome even to summarize the mass ${ }_{24}$ - of documents, petitions, answers, certificates, and decrees, 
that mark the history of this case, but a few of the leading features may be noticed. No sooner was Barker ejected than he presented a new petition, dated the 2oth February, 1620; this document, however, has not been found. In 1622 Norton presented a cross petition (Chancery Proceedings, James I., n. 7,44 ) in which he incidentally stated, that Barker, 'very unadvisedly used (for present money) to sell his books . . . before they were half printed, at half the prices he might otherwise have sold the same,' and so glutted the market. This statement, taken in connection with that already noticed in Barker's first petition, that certain stationers demanded money for imperfect copies, gives us, perhaps, the clue to what has for many years puzzled Bible students, namely, the innumerable variations found in the different issues of the Bible after $16 \mathrm{I} I$. The first edition of the Authorized Version was no doubt completed and issued at once, and a second edition put in hand. This last, however, and later ones, were printed in parts, when other work was slack, and these incomplete parts Barker sold whenever he could.

This bill of 1622 also hints at a statement that was made on the authority of certain other stationers who had been called in as auditors, that Norton had attempted to overreach Barker by charging $£ 3,000$ more for the stock in the office than he had given for it. It is interesting to note that at this time Humphrey Dyson was acting as counsel for Norton.

Recourse was again had to arbitration, the commissioners appointed on this occasion being Sir Ewbald Thelwall, Knt., Principal of Jesus College, Oxford, Philip Gerrard, and Thomas Jones. They presented their certificate on the 25th May, 1623, and it was thereupon decreed by the court that the terms were to be ratified and all other actions between the parties stayed (Chancery Decrees, 1622, p. 1003). By this award Barker was to be restored to the office and title of King's Printer on the payment of the sum of $£ 8,000$ at certain times, the payments to be made in the common 
dining hall of Gray's Inn. Each party was to appoint one person to see that the best profit was made from the office, 'the money was to be kept in a chest with Mr. Bills money, Mr. Nortons man to have a key to the chest and a key to the warehouses'; accounts to be audited by two stationers. But the most important clauses were those which were to enable Barker to pay the money. If he resolved to sell any lands which he had previously conveyed to his daughter-in-law as a jointure, Bonham Norton was to influence his daughter to consent to such sale, and Barker, on his part, was to obtain the consent of his son Christopher. As a recompense, he was to make over to his son and daughter-in-law the reversion of Southly, making proper provision, meantime, for their maintenance. Lastly, in view of the fact that the creditors of both parties were pressing for payment, the arbitrators petitioned the Lord Keeper to direct letters to them asking them to hold their hands for three years, interest being allowed at the rate of 10 per cent. Provision was also made for the younger children of Robert.

Nothing came of this decree. The fact was, Norton knew very well that Barker could not pay the money without the sale of lands, and he used his influence with his daughter to prevent Barker from selling the lands he had given her as a jointure, and although a writ of sequestration had been granted against him to John Bill and Matthew Lowndes, on the I 2th December previous, he determined to keep Barker out at any cost. What that cost was is shown by the statement that the creditors of both parties were getting impatient. So the matter dragged on from term to term and from year to year. On his accession, Charles I. confirmed the office of King's Printer to the then holders, Bonham Norton and John Bill. At length the Court of Chancery grew weary of the repeated evasions of Bonham Norton, and on his refusal to comply with their latest order, on the 5 th December, 1628 , ordered his committal to the Fleet Prison, in spite of his having 


\section{THE KING'S PRINTING HOUSE}

been chosen for the third time Master of the Company of Stationers for the year 1629 . Having thus vindicated the power of the law, the Court proceeded, on the 2oth Oetober, 1629 , to give its final judgment regarding the King's Printing House (Decrees, I629). Through this we get a further glimpse of Norton's actions. It appeared that he had made a conveyance of the office and stock to a kinsman of the name of Hungate on the 2.3rd March, 1621 , that is, almost directly after he had seized the office from Barker. But it was clearly proved that the matter was then in the hands of the court, Barker having entered a petition in February, 1620. The court therefore declared the conveyance void. It also expressed its disapproval of Norton's action in making a conveyance of the reversion of the office to his son Roger, upon his marriage three years before. It was decreed that Robert Barker the elder and Christopher his son should be forthwith restored to the moiety of the said office and the name of the King's Printer, and that Norton and all holding under him should deliver up possession of the same from the preceding 2oth September, and should reconvey the same to Barker. It was also incidentally mentioned that the office was then in Hunsdon House, Blackfriars.

So once more the imprint of the King's Printers became Robert Barker and John Bill, and all books found dated I 629 bearing their imprint, must have been printed after the 2oth October.

Subsequent events show that Bonham Norton was greatly enraged over this defeat, so much so that he made rash and dangerous speeches, which brought about his complete ruin and disgrace.

It is remarkable that although the Calendar of State Papers for this period has been in the hands of the public since 1860 , no one seems to have noticed the interesting series of documents relating to the Star Chamber case of the Attorney-General versus Bonham Norton and others, which was tried in July, 1630 (Domestic State Papers, 
Charles I., Vol. I69, Nos. 5, 6, 7, 20, 21 ; Vol. 175 , Nos. 123, I 24).

The defendants were fourteen in number: Bonham Norton, John Norton, his son, Sir Francis Ashley, Knt., Thomas Smyth, Thomas Hungate, Thomas Harper, John Troute, William Lewes, Richard Slake, Gyles Winston, Lawrence Lownes, William Lee, Robert May and Gyles Digges, and the charge against them was that of 'preferring a most false and scandalous petition to his Majestie against the Rt. Hon. the Lord Keeper,' and of 'raysinge and spreading abroad false tales and rumours concerning his Lordship and other great Lordes and other offences' $;$ in other words, of 'raising a false and infamous scandal of injustice and brybery, against the Lord Keeper, in making a decree betwixt Barker against Norton, for the office of King's Printer, and made 2oth Oct. last.'

The first of these papers is headed ' Causes specially to be heard this sitting,' the first and most important on the list being the case against Norton, and the paper has many marginal notes concerning the various defendants.

Thus John Troute and William Lewes are described as 'Norton's servants, who say that what they did was by commaundment of their master'; Gyles Winston is declared to have been 'a prisoner in ye Flette, where his acquaintance grew with Norton, he went to Serjeant Ashley for counsail'; Slack and Hungate, 'pleade not guiltie'; Sir Francis Ashley pleads 'that he did nothing except as a counsellor; and that he is not to discover his client's cause.'

The second paper gives an outline of the case with a running commentary. The heaviest indictment against the prisoners was that they had circulated a statement that Barker had bribed the Lord Keeper by a present of $£ 600$ made to his secretary. The 'other offences' with which they were charged included such as this: 4 Jany. 'hee [i.e. Norton] maketh a note of a relation of a health drunke by Mr. Barker's sone to a lady that did all the good, 
intending to cast the aspersion upon the Lord Keepers lady. Whereas its proved by him that drank the health and another in the company that it was drunke to an old woman, mother to one of the witnesses.'

The petition in which these charges were embodied was drawn up by John Norton, and presented by Susan, the wife of Roger Norton, another of Bonham Norton's sons.

It was proved on oath that Bonham Norton was very bitter against the Court of Chancery. He declared that Barker had procured the decree of 1619 by bribing Sir Francis Bacon with $£_{\mathrm{I}}, \infty 00$. He declared that the court was 'like hell' and 'worse than purgatory,' and that he believed everything was done by bribery.

His kinsman Hungate also declared that 'another decree might be had for money.' They both of them expressed the hope that the result of their action would be to drive the Lord Keeper from office, in which case Norton would be restored to the place of King's Printer.

On the other hand the Attorney-General shows that there was not a shred of proof produced by the defendants in support of their calumny; that it rested solely upon ale-house gossip. 'They cannot find soe much as a New Years gift at Christmas, onely a continuall usage of a vessell of wyhe paid by the kinge's printer.' The remaining papers are apparently notes made by defendants' counsel and the defence set up.

On the last of these papers are the following memoranda, which doubtless outline the punishment that was inflicted by the court.

'Bo: Norton. $3000^{\text {li }}$ to the $k$ : $3000^{\text {li damages to the }}$ Lord keeper. Imprisonment during his majesties pleasure. bound to good behaviour, submission. Confession of his faults in $y^{\mathrm{e}}$ Chancerie. Papers on his head.'

'John Norton. Ioooli fine, prison, confession and submission.'

Lee and May were each fined a thousand pounds, im- 
prisonment during life, "ye pillorie where to be nayled, bound to their good behaviour during life, confession, submission.' Sir Francis Ashley and other defendants were acquitted.

But the troubles of the King's Printing House were not over with the decree of 1629 , nor had the Court of Chancery heard the last of it. No sooner had the courts reassembled after Christmas than Robert Barker appeared declaring that on the decree of Oetcber, 1629, being pronounced, Norton and his agents, among them his two sons, John and Roger, broke into the printing ffice by night and carried off the stock and implements, so that neither the stationers nor the King's subjects could be supplied with books; and, further, that Bonham Norton refused to say where his son Roger was. As a result of this declaration, on the 12th May, 1630 , the court ordered all the persons named to be committed close prisoners to the Fleet, with leave to go abroad to attend the proceedings then pending against them in the Star Chamber. (Chancery Decrees, 1629 , A., pp. 59I, 608.)

It may here be mentioned that Hunsdon House, Blackfriars, to which the King's printing office had been removed by Norton was the scene of that memorable accident to a congregation of catholics, whe the floor gave way, and Father Drury the preacher and many others were killed. It was a great rambling place, very much after the style of Somerset House, and the King's printers appear to have had rooms in various parts of it. The rental of these offices was $£ 35$ per annum.

On the 5th May, I630, John Bill died, and his death caused a further alteration in the imprints of the King's Printing House, which now became 'Robert Barker and the assignes of John Bill,' those assigns being his son John, his executor, Martin Lucas, and others whose names have not come down to us. Robert Barker the second also seems to have died about this time, as we hear no 
more of him, and in 1634 Christopher the second died intestate, leaving a son, Christopher the third. Meanwhile, Robert Barker the elder was still in financial difficulties, and in 1634 he mortgaged his moiety of the office to Miles Flesher or Fletcher and his partners. On the 5th April in the following year, 1635, his great adversary, Bonham Norton, died, but whether he was a free man at the time or still a prisoner, there is no evidence to show. He was buried in St. Faith's, and a monument was erected in St. Paul's by his widow (Dugdale's ' St. Paul's,' p. 1 23), to whom administration of his effects was granted in the absence of any will. In the same year Robert Barker was committed as a debtor to the King's Bench prison, where he remained until his death in 1645 . $\mathrm{He}$ was still nominally the King's Printer, and all official documents continued to bear the imprint, "Robert Barker and the assignes of John Bill.'

In 1639 Charles I. marched north with an army to attack the Scots. Upon reaching Berwick-on-Tweed he sent to London for his printer and presses, and several pamphlets and proclamations bearing the imprint, 'Imprinted at Newcastle-upon-Tyne, by Robert Barker, Printer to the King's most excellent Majestie, and by the assignees of John Bill,' are still in existence ('Bibliographica,' vol. ii., pp. 280, 28 I). Clearly Robert Barker could not have gone to the King, and the printer of these papers has remained unknown. But among the Domestic State papers of the reign of Charles I. is one which clears the matter up. It is a certificate signed 'Joseph Ronscatt,' dated the $5^{\text {th }}$ February, I 643 , and relates to the trial of Archbishop Laud. It runs as follows:

'Mr. Legatt being too attende on the printing presses at Berwicke for his Majesties yoose at the first pasification he sent a nroclamation to the printing hoose in Blackfriars and the partners sent me with it to the Bishop to know his pleasure whether they should print it . . . but his answer was it was disonorable... and it should not 
be printed and was very angry at the secretary fordrawing it. But I have not the proclamation nor cannot mete with it now, nor the other for burning the papers, but their was such a one printed at the King's Printing hoose in Blackfriers.'

Undoubtedly then it was John Legatt, the son-in-law of Barker, who attended the King at that time. This document also bears out $\mathrm{Mr}$. Allnutt's conjecture, that the printer did not actually accompany the army, but sojourned for the time in some adjacent centre.

In another of these State Papers, Legatt is described as the 'farmer of the printing-house' (Dom. S. P. Chas. I. vol. 482 , No. 85).

On the 18 th March, $164 \mathrm{I}-2$, King Charles and his army entered York, and shortly afterwards a printing press was established there, and some thirty-nine pieces are known to have been printed at it between that date and September, I642. These all bear the imprint of Barker and Bill, or Barker only. In this case Legatt does not appear to have been the printer. In the seventh report of the Historical MSS. Commission (p. 84b), which deals with the records of the House of Lords, is a petition of Christopher Barker dated May 17th, I660. This was, of course, Christopher the third. He says that the office of King's Printer had been granted to his great-grandfather and grandfather for their lives and for thirty years after their decease. The surviving patentee died in 1646 , and the office then devolved upon petitioner for the remainder of the term of years, and he enjoyed it until sequestered for deliquency, then so called, viz. ' for carrying the printing presses to the city of York, as commanded by his late Majesty, whereupon the office was disposed of by the assumed government, to the almost undoing of himself, his wife and children.'

This can only refer to the York press of 1642 , and the inference is, that it was Christopher Barker the third who subsequently carried the presses to Nottingham, Shrewsbury and Bristol.

II.

c c 
Meanwhile, another claimant to a share in the Royal Printing House stepped forward, in the person of Matthew Barker, RoBert's youngest son. He declar a hat his father had in 1639 made an assignment of the 'usiness to him, and further that Christopher Barker the third had in 1642 granted him the moiety of the office. He had attempted to eject Miles Flesher and his partners, but unsuccessfully, and he further said that he had paid certain money for the assignment. There are two copies of this claim in the Record Office, and one has some important marginal notes, evidently made by the then lessees of the office, probably Hills and Field. They declare that Barker the elder, having previously mortgaged the office to Miles Flesher and his partners, had no power to make another assignment. They state that no money passed between the parties, and that it was in the nature of a letter of attorney given by Robert Barker to protect his interests. Matthew Barker, they declared, was himself an attorney, and therefore incapable of carrying on the printing office. In connection with this claim, a certain William Ball wrote a pamphlet in which he declared that the sole right of printing of the Bible was Matthew Barker's, in regard that his father paid for the amended or corrected translation 63,500 , "by reason whereof the translated copy did of right belong to him.'

Throughout the period of the Commonwealth the King's Printing House remained in the hands of Henry Hills and John Field, who, as Christopher Barker tells us, had been appointed by the assumed Government. But if we may believe the writer of a pamphlet, entitled 'The London Printers Lamentation, or, the Press opprest and overprest,' published about 1660, the manuscript copy of the Bible had been transferred to them by Barker and Bill for a consideration. ${ }^{1}$

1 - Have they. [Hills and Field] not invaded and still do intrude upon his Majestics Royall Privilege ...; and by the pusillanimous cowardice and insignificant compact of Master Christopher Barker [the 
Whatever the rights of this story, the Barkers, the Bills and the Nortons disappear from sight until the Restoration. All the patentees were naturally Royalists, and as soon as the King was restored, they clamorously shouted for recognition, and struggled to repossess themselves of the Royal Printing House. Christopher Barker the third was one of the earliest to apply for restitution in the petition that has already been quoted. Roger Norton, son of Bonham Norton, was not long behind him. Two of this printer's petitions are preserved in the State Papers (Dom. S. P. Chas. II., vol. xl., p. 118 ; Dom. S. P. Chas. II., vol. ii., p. $8 I$ ), and one of these is of special interest both on account of the statements contained in it, and the document which is annexed to it.

\section{'To the King's most excellent MA \\ ' The humble petition of Roger Norton Printer. \\ 'Sheweth \\ ' That yor pet $^{\mathrm{r}}$ hath a legall right to the moyety of} the Office of $\mathrm{Yo}^{\mathrm{r}} \mathrm{Ma}^{\text {ties }}$ Printer but debarred his right therein by a decree in Chancery $p^{r}$ tended to be made by the late Lord Keeper Coventry the legality of wch decree is now depending before the Lord Chancellor.

- Those now clayming to be yor $\mathrm{Ma}^{\text {ties }}$ printers and who of late have been imployed to print for yo $^{r}$ Matie are Gent. not brought up in the trade of printing or ever used it, and they are forced to heir others to print for them, and imploy those who allwaies printed for them who usurped the power dureing the late troubles.

younger] and another of his name, and (not without probable suspicion) by the consent and connivance of Master John Bill (though he was artificially defeated in his expectations of profit;) Have they not obtained (and now keep in their actual possession) the manuscript copy of the last translation of the Holy Bible in English.'-Arber's 'Transcript,' vol. iii., p. 28. 
' That yor $\mathrm{Ma}^{\text {tie }}$ at present hath noe setled printing office as vor Predecessors allwaies had, and the printing of the Bib and Service Book etc. being privilege inherent to yo $\mathrm{Ma}^{\text {tie }}$ and grantable and allwaies graunted to yor Mat ${ }^{\text {ies }}$ printers $w^{\text {ch }}$ priviledge was invaded by the late usurper Cromwell and granted by him to such persons who tooke upon them the name of his printers and continue to print Bibles and other Bookes belonging to $\mathrm{yo}^{\mathrm{x}} \mathrm{Ma}^{\text {ties }}$ printe:

'That yor Petrs father was one of the Printers to $y^{r}$ Majesties late father and Grandfather of blessed Memorie until ye said ptended decree and yor petitioner himself was brought up in the same trade and office and keepeth the same printing house and furnished with fitt and convenient Letters and all other materialls for printing.

' The premises considered yo $^{r}$ pet ${ }^{r}$ humbly prayeth yor $\mathrm{Ma}^{\text {tie }}$ will bee graciously pleased

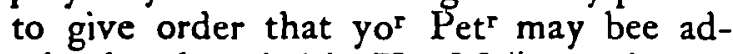
mitted and settled in $\mathrm{Yo}^{\mathrm{r}} \mathrm{Ma}^{\text {tien }}$ service.
'And yor Petr (as in duty bound) shall ever pray, \&rc. \&xc.

(I) 'Wee whose names are hereunder written doe certify that Roger Norton of London Printer during the time of his $\mathrm{Ma}^{\text {ties }}$ being beyond the seas, was very serviceable to his $\mathbf{M a}^{\text {tio }}$ in printing such letters declarations and papers as were conducing to his $\mathrm{Ma}^{\text {ties }}$ service. And further that hee at several times and upon severall occasions did conceale and entertaine at his house, soundry (sic) persons of trust and quality being employed by his $\mathrm{Ma}^{\text {tie }}$ from beyond the eas upon his most weighty affairs where they held frequent consultations concerning his $\mathrm{Ma}^{\text {ties }}$ service with other persons of honor and trust residing in and about London.

(Signed) 'Ossory' (eleven others).

No date. 
the King, as he was legally bound to do, recognized the claims of Christopher Barker and John Bill; but almost immediately Christopher Barker assigned his moiety of the office to George Sawbridge, Henry Hills, Kirton, Roycroft, Martin, and Mearne, for a sum of $£ 300$ down and an annuity of $f_{1}$ ioo per annum during the remainder of the patent, and annuities to his mother and sisters. This assignment, like everything with which the Barkers were connected, became the subject of lawsuits between him and both John Bill his partner, and Roger Norton. In the course of these we get another interesting reference to the manuscript of the 'Authorized Version.' It occurs in the action brought by Roger Norton against Christopher Barker concerning the printing of Statute Books, etc., and ' concerning the moiety of a manuscript of a Bible in English called the Bible of K. James his translation.' Norton declared that Barker in $166_{4}$ agreed to convey to him the remainder of his term, about twelve years, for a sum of $\ell_{0}, 300$, whereas the co-defendants, Sawbridge and Hills, recited the assignment above alluded to, including the manuscript of the Bible. In the end Barker was condemned in damages and costs, the bill against Roycroft, Martin, and Mearne was dismissed, and John Bill was to have precedence of Norton in all matters of payment (Enrolled Decrees, No. 688, P. R. O.)

Bagford has an interesting note concerning Roger Norton, which he took from Hearne's 'Life of Sir Thomas Bodley,' 1703.

- Mr. Roger Norton lived before the dreadful fier which consumed London in Black Friars, and had a proper house and garden adjoining to it on ye ground [on] which Mr. John Williams house standeth. He the said Norton was then in possession of the Kings printing office but being burnt out in Blackfriars took a house on Clerkenwell Green wher he continued for some time and ${ }_{2 s}$ there printed several books. At last he took part of 
Britan's House which formerly had been a noble pallas and toke up a grat dele of ground and reached to the gateway of the Grey Friars and had large gardens. And this house gave name first to letle Briten Strete, and likewise that which we call Duk lane, ye right name was Duke Lane leading into Smith or Smithfield and in that part of the Pallas he erected a printing office and therein printed severall bokes of his owne and other peoples copies. In time this house or palace came into the hands and possession of ye Mordens after[wards] Earls of Peterborough' (Harl. 5910, vol. iv., p. I58).

The remainder of the history of the King's Printing House under the Stuarts is soon told. Christopher Barker's name is found in all imprints in conjunction with those of his lessees and the assigns of John Bill until 1680, when his patent apparently ran out, and the name of Barker disappears from English printing. For the remainder of the Stuart period the descendants of John Bill and his partners Hills and Newcomb, carried on the business, and it was bought from them by John Baskett early in the eighteenth century.

The foregoing history is largely that of a squalid family quarrel; but $I$ hope it has made clear the causes of the extraordinary variations in the imprints of the books issued from the King's Printing House during the period it covers. It has revealed to us also: first, that the Barkers' printing house was in St. Martin's Lane, off Aldersgate Street, and was known as Northumberland House, and that it served as the King's Printing House until Bonham Norton removed the office to Hunsdon House, Blackfriars. It shows us, further, that it was John Legatt, Barker's son-in-law, who printed the series of documents bearing the Newcastle imprint, and Christopher Barker the third who had charge of the press at York in I642, and presumably at Nottingham and Bristol during the King's sojourn at those places. Finally, it shows that 
although the names of John Bill the second and Christopher Barker the third occur in the imprints of the Bible and Service Books till the close of the Stuart period, they were not the printers of those books, the actual holders of the King's Printing House being their assigns, Hills and Newcomb.

Henry R. Plomer. 